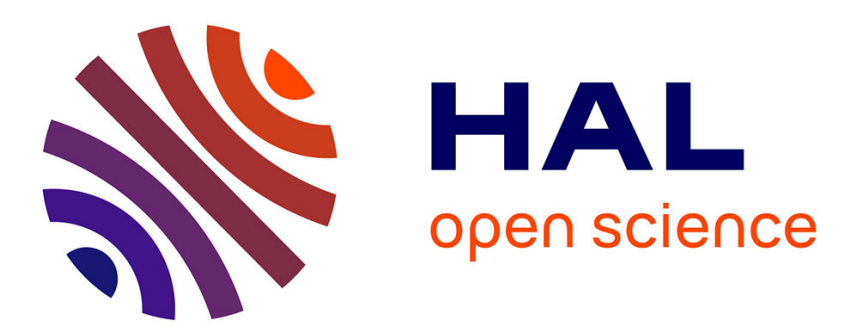

\title{
Structural context of the paleogeography of the Cenomanian-Turonian anoxic event in the eastern Atlas basins of the Maghreb

\author{
Mohamed Soua
}

\section{- To cite this version:}

Mohamed Soua. Structural context of the paleogeography of the Cenomanian-Turonian anoxic event in the eastern Atlas basins of the Maghreb. Comptes Rendus Géoscience, 2009, 341 (12), pp.1029-1037. 10.1016/j.crte.2009.07.003 . hal-00626299

\section{HAL Id: hal-00626299 \\ https://hal.science/hal-00626299}

Submitted on 25 Sep 2011

HAL is a multi-disciplinary open access archive for the deposit and dissemination of scientific research documents, whether they are published or not. The documents may come from teaching and research institutions in France or abroad, or from public or private research centers.
L'archive ouverte pluridisciplinaire HAL, est destinée au dépôt et à la diffusion de documents scientifiques de niveau recherche, publiés ou non, émanant des établissements d'enseignement et de recherche français ou étrangers, des laboratoires publics ou privés. 


\title{
Structural context of the paleogeography of the Cenomanian -Turonian anoxic event in the eastern Atlas basins of the Maghreb
}

\author{
Mohamed Soua ${ }^{\mathbf{a}}$, Oussema Echihi ${ }^{\mathbf{a}}$, Missoum Herkat ${ }^{\mathbf{b}}$, Dalila Zaghbib-Turki ${ }^{\mathbf{c}}$, Jalel \\ Smaoui ${ }^{a}$, Hela Fakhfakh-Ben Jemia ${ }^{a}$, Houda Belghaji ${ }^{a}$
}

a. Entreprise tunisienne d'activités pétrolières, ETAP-CRDP, 4, rue des Entrepreneurs, La Charguia II, 2035, Tunisie

b. Université des Sciences et de la Technologie Houari Boumediene BP 32 El Alia. Bab Ezzouar.Alger

c. Département des Sciences de la Terre, Faculté des Sciences de Tunis, Université Tunis El Manar, 1060 Tunis, Tunisia 


\section{Abstract}

The regional Cenomanian-Turonian (C/T) structural framework of surface and subsurface coupled with subsidence data inferred from palegeographic and organic-rich $\mathrm{C} / \mathrm{T}$ isopachs map, generated in this work, from several basins, wells and outcrops of Tunisia and eastern Algeria was investigated and provide constraints on the structural and sedimentary evolution of this part of the southern Tethyan margin during the $\mathrm{C} / \mathrm{T}$ times.

This period is characterized by the development of extensional structures with tilted blocks and grabens, bounded listric normal faults.

Subsidence during $\mathrm{C} / \mathrm{T}$ time led to the accumulation of a thick sequence of laminated black shales and marls (up to $80 \mathrm{~m}$ thick in northwestern Tunisia and about $100 \mathrm{~m}$ thick in the Aures-Kef trough in northeastern Algeria). Sharp variations in thickness and facies towards the $\mathrm{N}$ and $\mathrm{NE}$ indicate that basin subsidence was driven by regional tectonic movements along NW-SE, NE-SW and E-W trending normal faults issued from Tethyan rifting of the Upper Jurassic-Lower Cretaceous.

The reduction of emerged areas since the Cenomanian inferred from the generated palaeogeographic map is demonstrated.

The overall evolution is also maintened by halokinesis of Triassic salt creating subsident rim-synclines, where organic-rich facies prevail.

Key Words: Cenomanian-Turonian; Tunisia; Algeria; paleogeography; halokinesis ; Horsts and Grabens. 


\section{Résumé}

Le cadre structural régional du passage Cénomanien-Turonien $(C / T)$ couplé aux données de la subsidence déduit de la carte paléogeographique du $C / T$, généré dans ce travail, de plusieurs bassins, des puits et des affleurements de la Tunisie et de l'Algérie orientale a été l'objet de ce travail et a fourni de précieuses données sur la structure et l'évolution sédimentaire de cette partie de la marge sud de la Téthys au cours du passage C/T.

Cette période est caractérisée par le développement de structures extensives avec des blocs basculés, grabens et failles listriques.

La subsidence au cours du passage $\mathrm{C} / \mathrm{T}$ a conduit à l'accumulation d'une épaisse séquence de calcaire feuilleté et des marnes noirâtres (jusqu'à 80 m d'épaisseur dans le NW de la Tunisie et environ 100m d'épaisseur à travers le sillon Aurès-Kef en Algérie orientale). De fortes variations d'épaisseur et de faciès vers le $\mathrm{NE}$ et $\mathrm{N}$ indiquent que la subsidence du bassin a été stimulée par les mouvements tectoniques régionales le long de failles normales de directions NW-SE, NE-SW et EW issues du rifting Téthysien.

La réduction des zones emergées depuis la Cénomanien déduit de la carte paléogéographique est mis en évidence.

L'évolution globale est également amplifiée par les mouvements diapirique du Trias créant des rim-synclines subsidents, où les faciès riches en matière organique ont prévalu.

Mots clés : Cénomanien-Turonien ; Tunisie ; Algérie ; paléogéographie ; halocinèse ; Horsts et grabens 


\section{Introduction}

From the Late Triassic to the Cenomanian times, North Africa was characterised by an extensional regime associated with both the opening of the central Atlantic [e.g., 9; 29] and northward drift of the eastern part of the Apulian block $[11 ; 12,20 ; 34 ;]$.

Otherwise, the mid-Cretaceous is thought to be characterized by a decrease in the tectonic activity and the most intense Phanerozoic flooding event as the latest Cenomanian eustatic transgression $[14,15 ; 36]$ concomitant to the fast Atlantic seafloor spreading. Rifting occurred along the northern margin of the African plate as a result of left-lateral movement between the African and Eurasian plates, resulting in a complex horsts and grabens system trending NW to SE (Fig. 1) [12; 19; 20]. Associated fault displacements and uplift of horst blocks controlled sedimentation [20;21;27]. Compiling different data including seismic, sedimentological cross sections from petroleum wells or from outcrops integrated with previous works we tentatively present an isopachus Paleogeographic map of the Cenomanian-Turonian transition in the Maghrebian Estern Atlas basins in Tunisia and eastern Algeria (Fig.3)

Structurally and in a simplified manner, Tunisia and Algeria are composed of the Atlas Fold-and-Thrust belt to the north and the Saharan Platform south of the South Atlas Front (SAF) (Fig.1). They can be subdivided into (1) a northern alpine-deformed subsident zone with thick Mesozoic and Cenozoic strata and (2) a stable Palaeozoic province to the south where middle Jurassic-Late Cretaceous is relatively thin $[2 ; 3 ; 36]$. In general, Cretaceous sedimentation on the Saharan Platform has been poorly affected by tectonic movements [4], with the exception of local strike-slip movements (Fig.1). In 
the Atlas belt, however, deposition was strongly influenced by synsedimentary extensional phases.

\section{Structural setting}

The Cenomanian-Turonian organic-rich strata in onshore Tunisia/Algeria and offshore Tunisia are mainly found in the first province and the distribution of the organic content are strongly controlled by halfgraben systems $[1,13 ; 19,26,36]$ (Fig.4), and in some areas by Triassic salt diapiric movements $[30 ; 31 ; 36]$ during the Cretaceous (Fig.4; Fig.5).

The rift grabens formation is related to the opening of the Neotethys to the north [13] and Central Atlantic to the southwest [28].

Notably, this rifting in onshore and on the Shelf of Tunisia/Algeria did not begin before Late Jurassic-Early Cretaceous [13; 36]. However, late Triassic-Early Jurassic rifting is in fact associated with the separation of the eastern part of the Apulian micro-plate block $[9 ; 34]$ related at that time to the northern African Plate. Alternatively, in Morocco, during this period, related synrift sedimention consisted mainly of Jurassic carbonates and Early Cretaceous deltaic clastics where syndepositional rollover structures are developed [17] which might also have locally affected the anoxic Cenomanian-Turonian interval deposition.

So, two main Mesozoic rifting events occurred in this northern African margin (i.e. Algeria and Tunisia), namely (1) the Late Jurassic to Early Aptian, associated with E-W- 
trending halfgrabens and related volcanism e.g. in the Pelagian block, and (2) from the post-Aptian to Early Cenomanian, associated with NW-SE trending halfgrabens [12; 28]. In North Eastern Algeria, this extensional regime also resulted in the formation of graben and halfgraben systems, which controlled the distribution of carbonate platform and deeper basin facies, and therefore also of facies and organic richness of the $\mathrm{C} / \mathrm{T}$ interval [12; 16] (Fig.2; Fig.3; Fig.4).

These two recorded extensional phases were interrupted by a regional top-Aptian compressional phase (the Austrian phase) which is responsible for a typical unconformity detected in seismic profiles $[12 ; 18 ; 20 ; 21 ; 28]$ and in outcrops. The general graben trends are locally complicated by other faults which have partly dissected the grabens into smaller segments [6]. This top-Aptian compressional phase affected also the Saharan Platform (e.g., Berkine Basin) and resulted likely from transpressional movements along the $\mathrm{N}-\mathrm{S}$ trending Transaharian fracture system [12; 36].

Commonly, around $\mathrm{C} / \mathrm{T}$ times a general change from extension to compression occurred in North Africa, which was related to the closing of the Neotethys and the onset of North Atlantic rifting. This resulted in the inversion of the former rift grabens from the preceding extensional phase. However, some authors assume that the $\mathrm{C} / \mathrm{T}$ period was characterized by extension activities associated with a transtension and strike-slip movement $[16 ; 24 ; 25]$.

In Algeria, mid-Cretaceous extension was most intense in some localities [e.g. Constantine Basin, 5, 16], influenced by two principal extensional systems, the NE-SW 
trending Aurès-Kef trough to the north and the NW-SE trending Negrine-Gafsa Trough to the south, The first direction is probably inherited from the Tethys rifting; the second corresponds to the direction of the Sirt rift system. (Fig.1; Fig.3; Fig.4).

Extensional Infracretaceous tectonics [8] was used to explain Cenomanian-Turonian halfgraben tectonics, resulting in fragmentation into small tectonic blocks [7].

Some authors assume that the rift movements were somehow blocked [e.g. 13] or were restrained [6] during the anoxic Cenomanian-Turonian deposition.

In northwestern and central Tunisia as well as on the Pelagian Province, Cretaceous diapiric movements of Triassic salt played a role locally in controlling C/T deposition, [6, 31; 36] (Fig.3; Fig.4; Fig.5). They are characterized by a marked thickness reduction and partly by development of a detrital level (sandstones, conglomerates) [31, 36]. The diapiric rise, starting from Aptian (and even before) to approximately middle Eocene was probably continuous, but it increased during periods of tectonic instability $[31 ; 13$; 36]. Thus earlier diapiric movements and rise-up are super-imposed to the extensional features favouring depocenters individualisations in the central parts of rim-synclines

(Fig.3; Fig.4; Fig.5). In the Eastern foreland i.e. east of the $\mathrm{N}-\mathrm{S}$ axis, seismic interpretations by Khomsi et al. [20; 21] allowed to visualise properly such features (Fig.5).

\section{Cenomanian-Turonian palaeogeography map}

Combination of $\mathrm{C} / \mathrm{T}$ data identified a number of major features characterizing a key period of geological history of Tunisia and eastern Algeria. 
During the C-T times, Tunisia and eastern Algeria, situated at the southern Tethyan margin were characterised by a general slope almost dipping to the north, promoting variable facies ranging from littoral (Saharan platform), shelfal and probably lagoonal (southeastern Tunisia) to bathyal (central and northern Tunisia). The general facies trend was related to a complex tectonic and halokinetic paleo-elevation resulting in variations of the $\mathrm{C} / \mathrm{T}$ facies $[2 ; 30 ; 36 ;$ Fig.3].

Organic-rich $\mathrm{C} / \mathrm{T}$ sediments occur in many places in northern, central and offshore Tunisia and are grouped into the Bahloul Formation. The thickness distribution of the anoxic C/T facies in Tunisia and Algeria is illustrated in Fig.3. The regional distribution of the Tunisian $\mathrm{C} / \mathrm{T}$ facies including the distinction of an organic-rich and an organic-lean anoxic facies, is shown in three main Provinces (Fig.3). Mainly it is represented in Hodna basin, Aurès-Kef Trough (eastern Algeria), onshore NW Tunisia, in the Gulf of Hammamet - Gabes and locally in the Negrine-Gafsa Trough (Fig.3). Well and outcrop data confirm these organic-rich provinces, and the exact boundaries have been clearly traced through this study, especially north of the Gulf of Gabes belt. Dealing with the Soua and Tribovillard, [36]'s model, the palaeogeographic setting suggest that the distribution of the organic-rich facies represents the impingement of an Oxygene Minimum Zone [OMZ] onto the southern Tethyan margin. This latter facies is generally 10-30 meters thick, with a maximum thickness of $80 \mathrm{~m}$ recorded in the NW Tunisia (Hammem Mellègue section, Fig.3, Fig.4), and it consists generally of shale and limestone alternations. Limestone is dark and thinly laminated wackstone/packstone, 
whereas, shale is organic-rich laminated black shales with TOC values up to $14 \%$ [33; 36].

In Zaghouan-Bargou area (Fig.3; Fig.4), the latest Cenomanian-early Turonian black shales facies [34] may continue up to the early Coniacian age. The same age-equivalent black shales are present in Venezuela under Laluna Formation name [34].

Thus, it appears that the paleogeographic distribution, regional lithofacies, and areas of subsidence were depending on the sea level fluctuation and/or tectonic movements (Fig.3; Fig.4). During this interval, installation of the major uppermost Cenomanian transgression took place inducing the filling of the paleostructures and extension of the open marine sedimentation.

According to Grasso et al, [13] an Aptian-Cenomanian rifting phase took place on the Tunisian shelf and extending towards the $\mathrm{N}-\mathrm{S}$ axis [37] to the south along the Tripolitania - Jarrafa - Sirte basins [3; 19] (Fig.1). Extension and normal faults during late Cenomanian-early Turonian can be inferred from seismic records [20; 21] (Fig.4). No deposition of the anoxic C/T carbonate on uplifts and paleohighs is recorded [Fig.3; Fig.4]. During that time, subsidence led to the accumulation up to $80 \mathrm{~m}$ of laminated black shales in a time span of about $0.4 \mathrm{Ma}$ at least in the Tunisian sections [35]. In summary, we note the reduction of emerged areas since the Cenomanian: (Fig.3). -To the West the subsidence is controlled by a preferential NE-SW faulting trend (Aures basin-Kef) where maximum $\mathrm{C} / \mathrm{T}$ subsidence is recorded.

-To the SW, the subsidence is controlled by a preferential E-W faulting trend.

-To the E the subsidence is mostly controlled by NW-SE faults. 
-To the Central and Southern domains there is development of a wide platform with low subsidence rate (Fig.3; Fig.4).

\section{Cenomanian-Turonian tectonic evolution}

Basin formation dynamics during the $\mathrm{C} / \mathrm{T}$ time, in Tunisia and eastern Algeria is characterized by subsidence heterogeneity due to the complex structural organization. Everrywhere in the studied area, structural evidence shows that this margin was under extension from Triassic until late Cretaceous. Basins geometry reflects the inherited pattern of highs and sub-basins, which can be the result of a combination of several mechanisms including Triassic salt movement and extensional regime. Schematic crosssectional model is used here (Fig.4) to explain our point of view in order to understand Tunisian and eastern Algerian basins formation during $\mathrm{C} / \mathrm{T}$ times. So, we propose to give an overview of major structural domain and their tectonic evolution related to tectonic subsidence.

\section{Structural domains during the $\mathrm{C} / \mathrm{T}$ transition time}

During the $\mathrm{C} / \mathrm{T}$ time the southern Tethyan margin was organized as several trending Horst and Graben systems, which are from West to East:

- NE-SW in the pre-Atlas domain

- E-W and NE-SW in the Aurès-Kef Trough

- NW-SE to WNW-ESE in Negrine- Gafsa Trough

- NW-SE in eastern Tunisia 
We note that these tectonic provinces are characterized by synsedimentary normal faults, which controlled facies and thickness variation from south to north and from west to east (Fig.3). Late Cenomanian-Early Turonian strata become thicker and organic-rich in subsident domains (Aures-Kef Trough, Negrine-Gafsa Trough, Kerkenah basin and Hodna basin; Fig.3) and carbonate facies with low subsidence on resistant blocks.

At late Cenomanian-early Turonian, a large part of Tunisia and eastern Algeria were flooded by the major eustatic transgression that is thought to have been the most intense Phanerozoic flooding event [e.g 15; 36].

During this interval, the structural framework is dominated by tilted blocks which underwent individualizing subsidence zones with variable rates (Fig.3). They are characterized by high subsidence rates (e.g. Mellegue: 200m/Ma; Bargou: 160m/Ma; Gafsa: 120m/Ma [35]; Pre-Atlas and Aurès-Kef Trough: more than 250m/Ma [5]; Kerkenah area: $110 \mathrm{~m} / \mathrm{Ma}[32])$.

In eastern Algeria, the thickness increases towards the Aurès-Kef Trough, the Hodna basin and Negrine-Gafsa Trough (Fig.3). Synsedimentary normal faults emphasise an extensional event with a regional tilting eastwards and northwards. We note that the behaviour become deeper from South-west to North-east (Fig.3; Fig.4).

Alternatively, Tunisia has the same structural evolution manifested by tilted blocks with an increase of the subsidence. The thickness increases towards the north and the northeast (Fig.3). This trough organisation is closely related to the Africa-Eurasia relative movement, the opening of the North-Atlantic Ocean in the West and the Sirt basin rifting in South-east (Fig.1). 
Resistant blocks are also trending NE-SW, E-W and NW-SE and are genetically related to inherited structures characterised by low and slow subsidence amplitudes (Fig.3; Fig.4). The $\mathrm{C} / \mathrm{T}$ subsidence is mainly due to extensional regime coupled with Triassic salt movements and eustasy (Fig.3; Fig.4; Fig.5)

\section{Conclusion}

The regional $\mathrm{C} / \mathrm{T}$ tectonic evolution, coupled with subsidence interpreted from palegeographic and $\mathrm{C} / \mathrm{T}$ isopachous maps on several basins, wells and outcrops of Central Tunisia and Northeastern Algeria [eg. $5 ; 10 ; 12 ; 16 ; 20 ; 21 ; 22 ; 24 ; 36$ ] provide valuable constraints on the $\mathrm{C} / \mathrm{T}$ structural and sedimentary evolution of this part of the southern Tethyan margin (Fig.4). Crustal extension along this margin of the African plate started during the Early Cretaceous, however, continental break-up is thought to be occurring at about $180 \mathrm{Ma}$. Subsidence during $\mathrm{C} / \mathrm{T}$ time led to the accumulation of a thick sequence (up to $80 \mathrm{~m}$ thick in Mellegue area, NW Tunisia and about 100m thick through the Aures-Kef trough, NE Algeria; Fig.3) of laminated black shales and marls. Sharp variations in thickness and facies towards the $\mathrm{N}$ and $\mathrm{NE}$ indicate that basin subsidence was driven by regional tectonic movements along NW-SE, NE-SW and E-W trending normal faults issued from Tethys and Sirt rifting riftings. The overall evolution is also amplified by Triassic diapirism creating subsident rim-synclines allowing stratified water conditions and high preserving sedimentation rates that occurred later during Upper-Cretaceous (Fig.3; Fig.4; Fig.5). 


\section{References}

[1] H., Abdallah, C., Meister, The Cenomanian-Turonian boundary in the Gafsa- Chott area [southern part of central Tunisia]: biostratigraphy, palaeoenvironments [1997]. Cretac. Res. 18, pp. 197-236.

[2] W.F. Bishop, Petroleum geology of East-Central Tunisia, AAPG Bull. 72 [9] [1988] $1033-1054$.

[3] P.F., Burollet, Structures and tectonics of Tunisia: [1991], Tectonophysics, 195, pp. 359-369.

[4] G., Busson, Mesozoic of southern Tunisia, in Guidebook to the geology and history of Tunisia: [1967] Petroleum Exploration Society of Libya, Ninth Annual Field Conference, pp. 131-151.

[5] R., Bracène, M., Patriat, N, Ellouz, JM, Gaulier. Subsidence history in basins of northern Algeria [2003]. Sedimentary Geology, 156, pp. 213-239.

[6] G.F., Camoin, Sedimentologic and paleotectonic evolution of carbonate platforms on a segmented continental margin: example of the African Tethyan margin during Turonian and Early Senonian times [1991]. Palaeogeogr. Palaeoclimatol. Palaeoecol. 87, pp. 29- 52.

[7] A., Charrière, Contexte paléogéographique et paléotectonique de la formation des bassins crétacés du Moyen Atlas [Maroc] à la lumière des données stratigraphiques récentes [1996]. Bull. Soc. Géol. Fr. 167 [5], pp. 617- 626 
[8] R., Ensslin, Cretaceous synsedimentary tectonics in the Atlas system of central Morocco [1992]. Geol. Rundsch. 81, pp.91- 104.

[9] A., Flexer, A., Rosenfeld, S., Lipson-Benitah, A., Honigstein, Relative sea level changes during the Cretaceous in Israel [1986]. AAPG Bull. 70, pp. 1685-1699.

[10] D. Frizon de Lamotte, P. Leturmy, Y. Missenard, S. Khomsi, G. Ruiz, O. Saddiqi, F. Guillocheau and A. Michard, 2008, Mesozoic and Cenozoic vertical movements in the Atlas system [Algeria, Morocco, Tunisia]: An overview, Tectonophysics.

[11] W.K., Gealey, Plate tectonic evolution of the Mediterranean-Middle East region [1988], Tectonophysics 155, pp. 285- 306.

[12] R., Guiraud, Y., Bellion, J., Benkhelil, C., Moreau, Post-Hercynian tectonics in northern and western Africa, [1987]. Geol. J. 22, pp. 433- 466.

[13] M., Grasso, L., Torelli, G., Mazzoldi, Cretaceous- Palaeogene sedimentation patterns and structural evolution of the Tunisian shelf, offshore the Pelagian islands [central Mediterranean] [1999]. Tectonophysics 315, pp. 235- 250.

[14] B., Haq, J., Hardenbol, P.R., Vail, Chronology of fluctuating sea levels since the Triassic [1987] Science 235, pp.1156-1167.

[15] J., Hardenbol, J., Thierry, M.B., Farley, T., Jacquin, P.-C., De Graciansky, P.R., Vail, Cretaceous sequence chronostratigraphy [1998],In: De Graciansky, P.-C., Hardenbol, J., Jacquin, T., Vail, P.R. [Eds.], Mesozoic and Cenozoic Sequence Stratigraphy of European Basins. Soc. Econ. Paleontol. Mineral. Spec. Publ., 60. Chart 4; Tulsa 
[16] M., Herkat, J., Delfaud, Genèse des séquences du Crétacé supérieur des Aurès [Algérie]. Rôle de l'eustasime, de la tectonique, de la subsidence: une mise au point. [2000].C. R. Acad. Sci., Sér. IIa 330, pp. 785- 792.

[17] M.A.W., Heyman, Tectonic and depositional history of the Moroccan continental margin. [1990]. In: Tankard, A.J., Balkwill, H.R. [Eds.], Extensional Tectonics and Stratigraphy of the North Atlantic Margins. AAPG Memoir, vol. 46, pp. 323- 340.

[18] H., Ibouh, F., Zargouni, Nouvelles données sur la tectonique synsedimentaire du Crétacé inférieur et le début du Crétacé superieur au niveau de la jonction des Jebels Orbata et Bouhedma [Tunisie meridionale]. [1998]. Afr. Geosci. Rev. 5, pp. 207-215.

[19] D., Jongsma, J.E., van Hinte, J.M., Woodside, Geologic structure and neotectonics of the North African continental margin south of Sicily [1985] Mar. Pet. Geol. 2, pp. $156-179$

[20] S. Khomsi, M. Bédir and M.G. Ben Jemia, Mise en évidence et analyse d'une structure atlasique ennoyée au front de la Chaîne alpine tunisienne, C.R. Geosci. 336 [2004], pp. 1293-1300.

[21] S. Khomsi, M. Bédir and M.G. Ben Jemia, Mise en évidence d'un nouveau front de chevauchement dans l'Atlas tunisien oriental de Tunisie par sismique réflexion. Contexte structural régional et rôle du Trias salifère, C.R. Geosci. 336 [2004], pp. 1401-1408.

[22] N., Kazi-Tani, Evolution geodynamique de la bordure nord africaine: le domaine intraplaque nord algérien, approche sequentielle. [1986] These sd. Univ. Pau, 2 vol., $871 \mathrm{pp}$. 
[23] E., Laville, Evolution sedimentaire, tectonique et magmatique du bassin jurassique du haut Atlas [Maroc]: modele en relai multiple de decrochement. [1985]. These Sci. Univ. de Montpellier. 166 pp.

[24] S., Luning, S., Kolonic, E., M., Belhaj, Z., Belhaj, L., Cota, G., Baric and T., Wagner, An integrated depositional model for the Cenomanian-Turonian organic-rich strata in North Africa [2004] Earth Science reviews, 64, Issues 1-2. Pp 51-117.

[25] A.L. Maâmouri, D. Zaghbib-Turki, M.F. Matmati, M. Chikhaoui, J. Salaj, La Formation Bahloul en Tunisie centro- 700 M. Soua, N. Tribovillard / C. R. Geoscience 339 [2007] 692-701 septrentionale : variations latérales, nouvelle datation et nouvelle interprétation en terme de stratigraphie séquentielle, J. Afr. Earth Sci. 18 [1] [1994] 3750.

[26] M.A., Morgan, J., Grocott, and R.T.J., Moody, The structural evolution of the Zaghouan-Ressas Structural Belt, northern Tunisia [1998], in Macgregor, D.S., Moody, R.T.J., and Clark-Lowes, D.D., eds., Petroleum geology of North Africa: Geological Society, London, Special Publication 132, pp. 405-422.

[27] J.-C., Maurin, Guiraud, R., Basement control in the development of the Early Cretaceous west and central African Rift System [1993]. Tectonophysics 228, pp. 8195.

[28] R., Oyarzun, M., Doblas, J., Lopez-Ruiz, J.M., Cebria,. Opening of the central Atlantic and asymmetric mantle upwelling phenomena: implications for long-lived magmatism in western North Africa and Europe [1997] Geology 25, 727- 730. 
[29] V., Perthuisot,. Diapirism in northern Tunisia [1981]. J. Struct. Geol. 3, pp. 231235.

[30] J.J. Orgeval,. Peridiapiric metal concentration: example of the Bou Grine deposit [Tunisian Atlas] [1994] In: Fontboté/Boni, [Ed.], Sediment-Hosted Zn -Pb Ores. Spec. Publ. 10, Soc. Geol. Applied to Mineral Deposits Springer, Berlin, pp. 354- 389.

[31] M., Patriat, N., Ellouz, Z., Dey, J. M., Gaulier, H., Ben Kilani. The Hammamet, Gabes and Chotts basins [Tunisia]: a review of the subsidence history [2003], Sedimentary Geology, 156, pp.241-262.

[32] F., Robaszynski, M., Caron, C., Dupuis, F., Amedro, J.M., Gonzalez-Donso, D., Linares, J., Hardenbol, J., Gartner, F., Calandra, R., Deloffre, A tentative integrated stratigraphy in the Turonian of Central Tunisia : Formations, zones and sequential stratigraphy in the Kalaat Senan area [1990] Bull. Centres Rech. Explor. Prod. ElfAquitaine, 14 / 1, pp. 213-384.

[33] M., Saidi, H., Inoubli, Geochemistry and organic petrography of proven Tunisian souce rocks [2001] 20th International Meeting of Organic geochemistry (Nancy 2001).

[34] J., Salaj, The geology of the Pelagian block; The eastern Tunisian platform, in Nairn, A.E.M., Kanes, W.H., and Stehli, F.G., eds., The ocean basins and margins; The western Mediterranean [1978], New York, Plenum Press, pp. 361-416.

[35] M., Soua, Application of the Time series analysis to the Latest Cenomanian - Early Turonian sequence in the southern Tethyan margin.

[36] M Soua M., and Tribovillard N. 2007 Depositional model at the C/T boundary for the Bahloul Formation, Tunisia. Comptes rendus - Geoscience , 339 [10] pp 692-701 
[37] C., Soyer, P., Tricart, Tectonique d'inversion en Tunisie centrale: le chainon atlasique Segdale-Boudinar [1989]. Bul. Soc. Geol. Fr. 5, pp. 829- 836. 


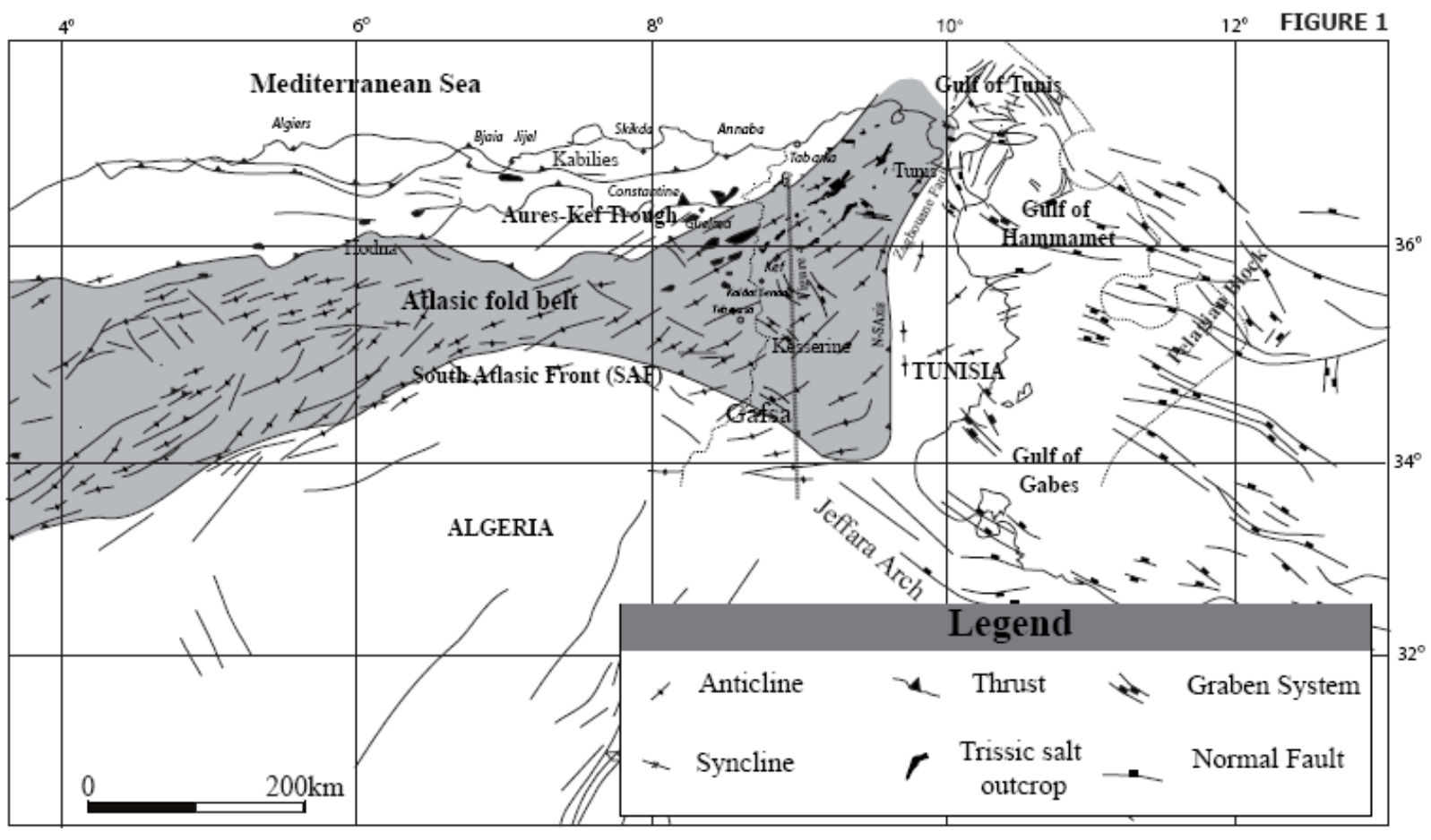

Figure1 Tectonic map of the eastern Maghrebian Domain, age and nature of the main structural elements across North Africa. The outline of the major Mesozoic basins is well reflected in the pattern of subcropping stratigraphy modified from $[5,10,12,16$ and 31$]$ Figure1 Carte structural du domaine maghrébin oriental, age et nature des principaux éléments à travers l'Afrique du Nord. L'esquisse des principaux bassins mesozoiques est très connue en subsurface, modifiée de $[5,10,12,16$ et 31$]$. 


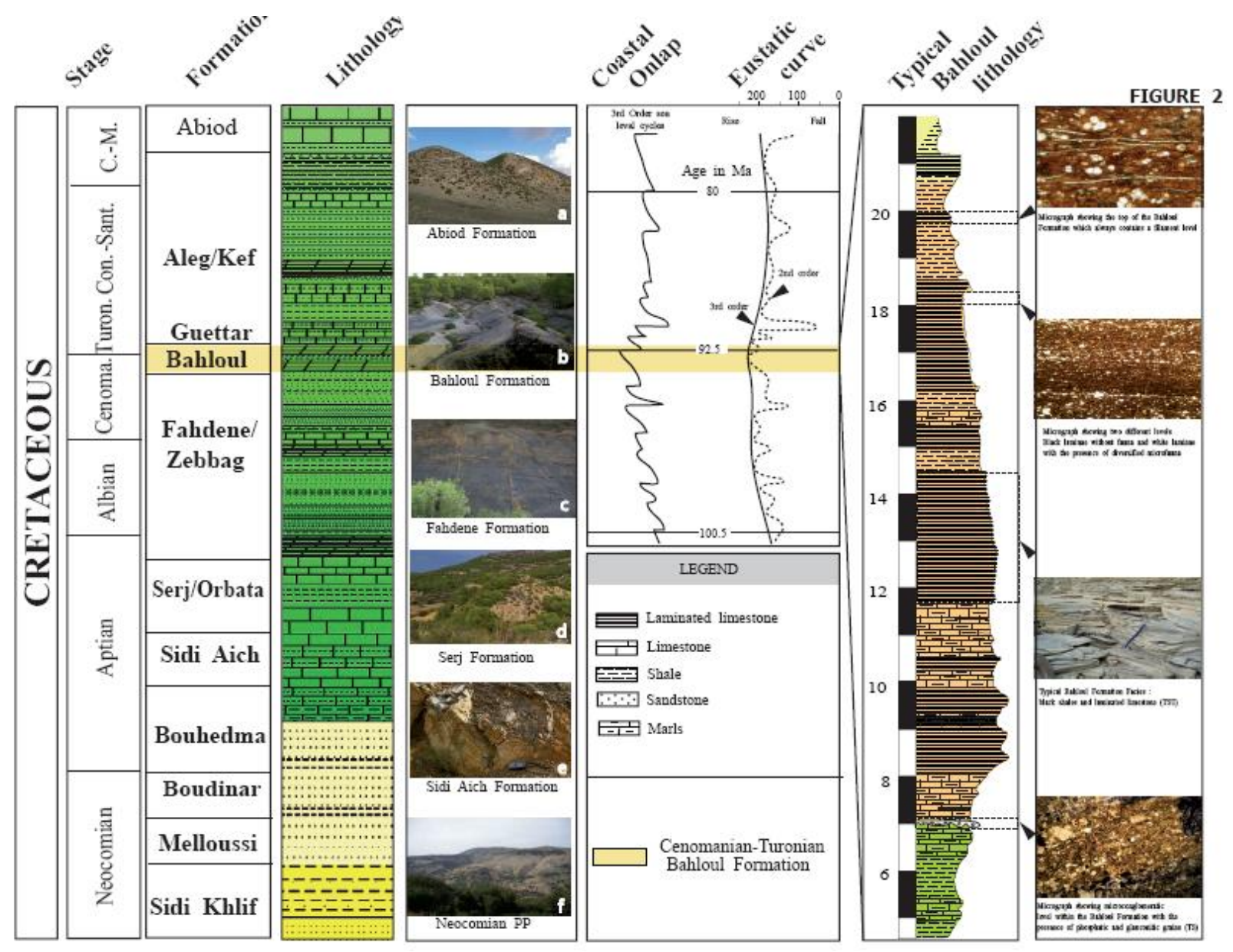

Figure 2 Identification of the Bahloul Formation, main lithology and characteristics superposed to the global eustatic and coastal onlap curves of Haq et al. [14] and Hardenbol et al. [15], Cretaceous lithology as defined by Burollet [3]. Note that the pictures a-d are taken from El Kef area and the pictures e and $f$ are taken from Gafsa area.

Figure 2 Identification de la Formation Bahloul, les caractères généraux et principale lithologie superposée à la courbe eustatique globale de Haq et al. [14] et Hardenbol et al. [15]. Les photos a-d sont prises dans la region d'El Kef, les photos e et $f$ sont prises dans la région de Gafsa. 


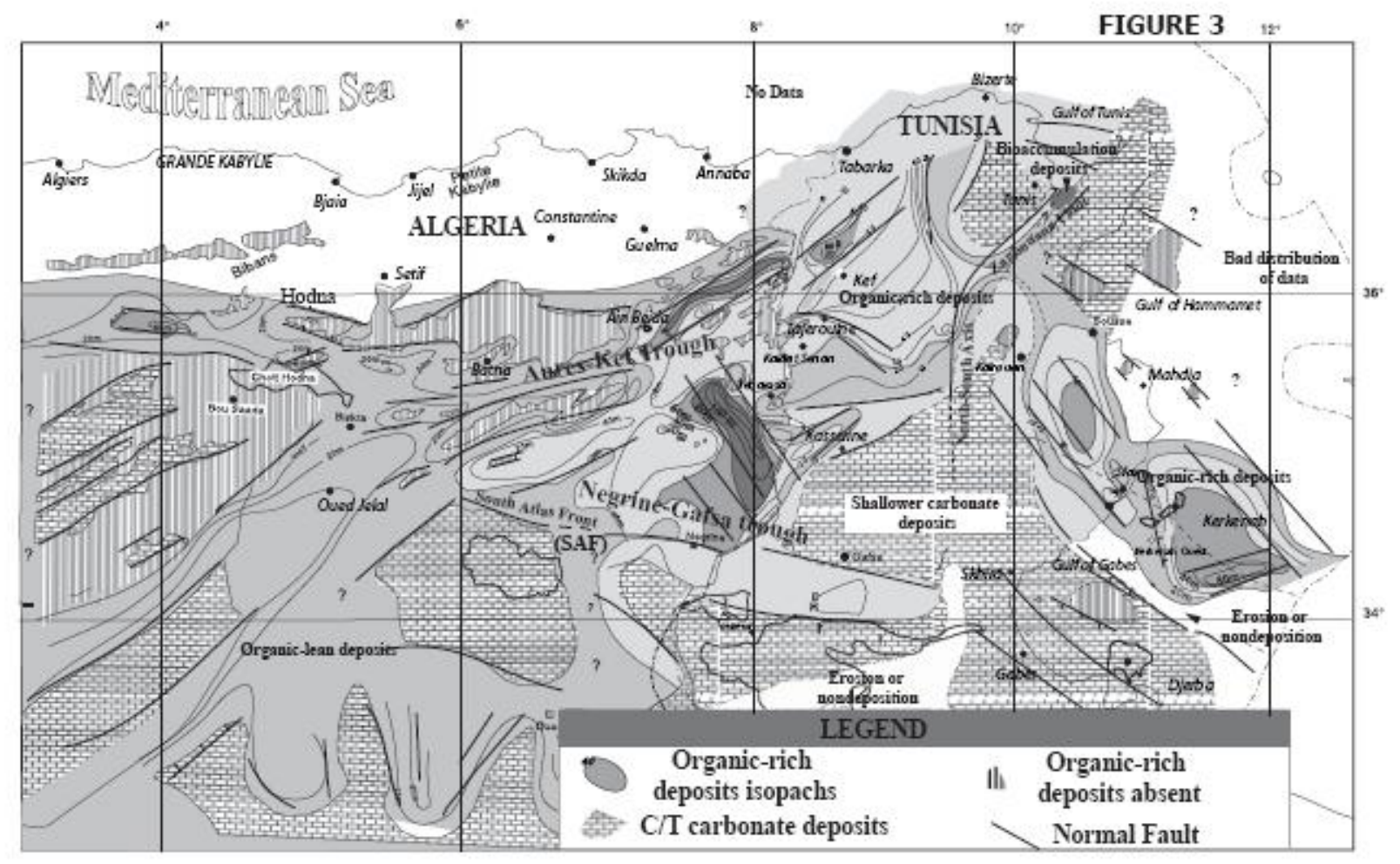

Figure 3 Facies and thickness of the Organic-rich Late Cenomanian- Early Turonian and age equivalent units in Tunisia and Eastern Algeria superposed on the Structural setting of the eastern Maghrebian Domain during the $\mathrm{C} / \mathrm{T}$ transition (inferred from the palaeogeographic map). Note the E-W trending faults are related to the Tethys rifting and the NW-SE trending faults are related to the Sirte rifting [e.g. 10 and references therein]. Base map and isopach data modified after $[2,24,32,33,36]$; facies zones modified after $[2,24,36]$. Note that the isopach trends illustrated are simplified and short-distance thickness, and facies changes occur, related to the complex tectonohalokinetic palaeorelief at the time (see Figure 4). Organic-rich and carbonate or age equivalent units are not present on present palaeohigh.

Figure 3 Faciès et épaisseur des sediments riches en matière organique du Cénomanien-Turonien et leurs équivalents latéraux en Tunisie et en Algérie orientale 
superposée sur le cadre structurale du domaine maghrébin oriental durant le passage $\mathrm{C} / \mathrm{T}$ (déduit de la carte palégéographique). Noter que les failles de direction $\mathrm{E}-\mathrm{W}$ sont liées au rifting Téthysien et que les failles de direction NW-SE sont liées à l'ouverture de bassin de sirte [e.g. 10 et les références citées dans cet article]. La carte de base et les isopaques sont modifiés de $[2,24,32,33,36]$; les zones de passage de faciès sont modifiés de $[2,24,36]$. Notez que les isopaques illustrés sont simplifiés avec des distances courtes, et le changement de faciès est lié au complex paléo-reliefs tectonohalocinétiques (voir Figure 4). Les sédiments $C / T$ ne sont pas présents sur les paléohaufonds.

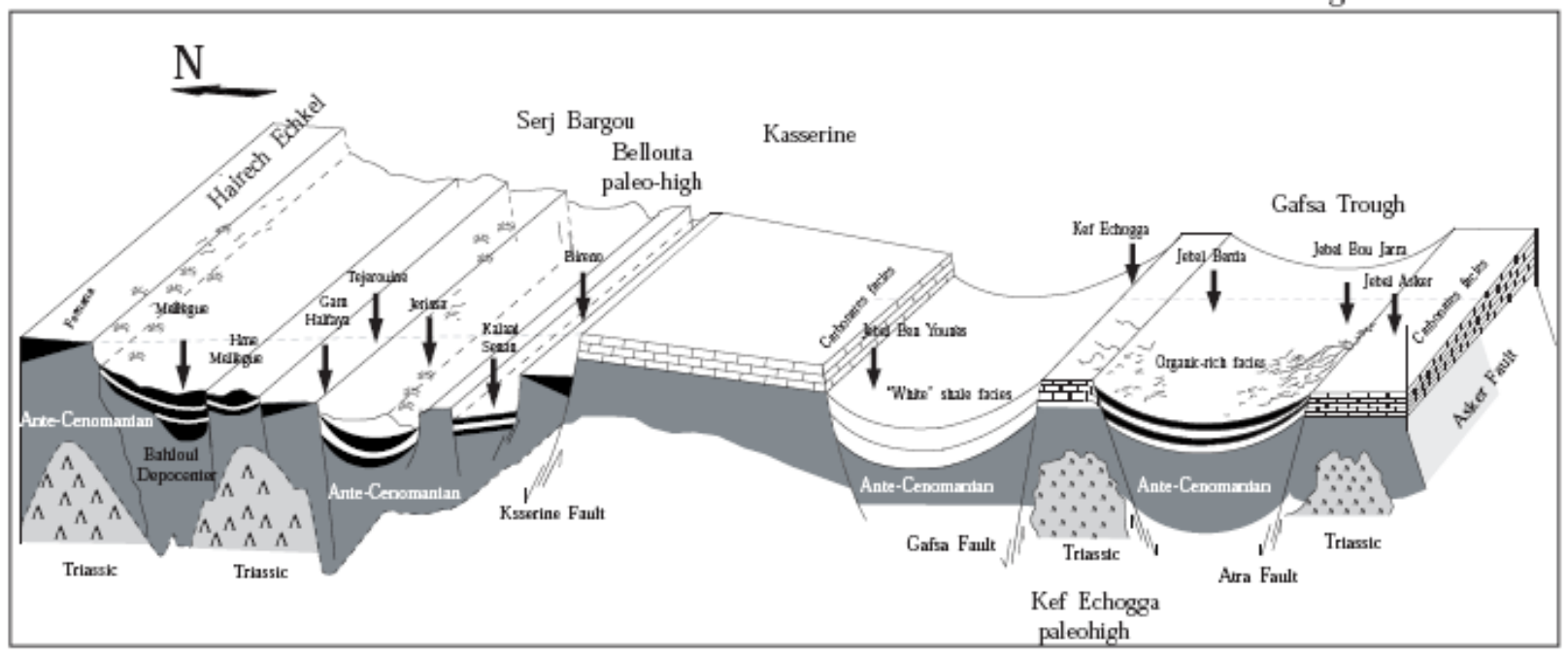

Figure 4 The Cenomanian-Turonian sedimentation evolution amplified by Triassic diapirism creating subsident rim-synclines allowing stratified water conditions and high preserving sedimentation rates that occurred later during Upper-Cretaceous.

North-South cross-sectional model along Mellegue-Kasserine-Gafsa trough. Data compiled after $[1,30,32,33$ and 36]. Note that Mellegue recorded 80m thick laminated 
black shales and is considered as the Tunisian depocenter of the Cenomanian-Turonian sedimentation (lateral and vertical scale not considered).

Figure 4 Evolution de la sédimentation du Cénomanien-Turonien est amplifié par le diapirism Triasic créant des rime-synclines subsidents permettant la stratification de la colonne d'eau et la préservation des sédiments riches en MO qui seront déposés ultérieurement au cours du Crétacé supérieur. Une coupe transversale le long d'un transect Nord-Sud : Mellegue-Kasserine-Sillon de Gafsa. Les données sont compilées d'après $[1,30,32,33$ et 36]. Notez que la région du Mellegue a enregistré $80 \mathrm{~m}$ d'épaisseur de calcaire noirs laminé riche en MO et elle est considérée comme le déponente tunisien de la sédimentation C/T.

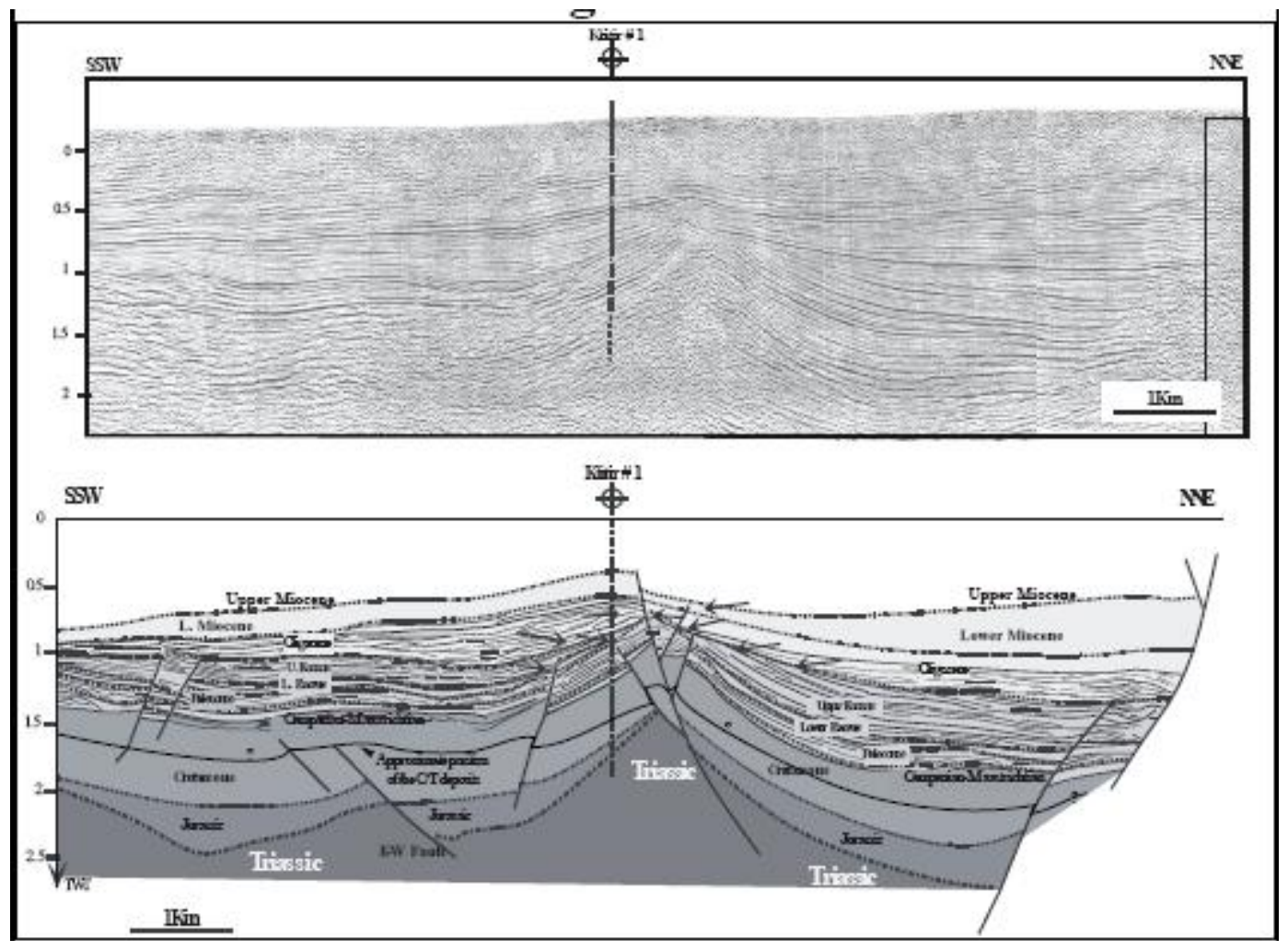

Figure 5 Seismic interpretation in the Sahel foreland of the Atlas outlining Triassic salt movements linked to Tethyan Late Jurassic- Early Cretaceous rifting and subsequent 
thickening of the Cretaceous series in rim-synclines (adapted from Khomsi et al. [20]). Note that $\mathrm{C} / \mathrm{T}$ evolution is influenced by Triassic diapirism creating subsident rimsynclines allowing stratified water conditions and high preserving sedimentation rates that occurred later during Upper-Cretaceous. In this Figure an attempt was carried out to draw the approximate $\mathrm{C} / \mathrm{T}$ organic-rich sediments.

Figure 5 interprétations sismiques dans le Sahel mettant en relief d'une part les mouvements salifères du Trias liés au rifting Téthysien du Jurassique supérieure-Crétacé inférieure et d'autre part l'épaississement du Crétacé dans les rim-synclines. (adapté de Khomsi et al. [20]). Notez que l'évolution de la sédimentation C/T est influencée par le diapirisme qui a crée des rim-synclines subsidents permettant des conditions de stratification de la colonne d'eau et la préservation des sédiments riches en MO. 